TILTAI, 2015, 1, 99-113, ISSN 1392-3137 (Print), ISSN 2351-6569 (Online)

\title{
NEAPIBRĖŽTUMO ASPEKTAI SOCIALINIAME DARBE
}

\author{
Valdas Rimkus \\ Klaipédos universitetas
}

\begin{abstract}
Anotacija
Straipsnyje analizuojama neapibrèžtumo šiandieniniame socialiniame darbe problema postmodernios pasauležziūros įsigalèjimo kontekste, išskiriant ontologinį, epistemologinị ir procedūrinị neapibrezžtumo aspektus. Remiantis teorinėmis ịvairių autorių įžvalgomis, kritinis mąstymas, žmogaus teisių diskursas, kliento stiprybes akcentuojantis socialinio darbo modelis pristatomi kaip galimos alternatyvos priimant sprendimus kompleksiškoje šiandienos realybejje.

PAGRINDINIAI ŽODŽIAI: neapibrěžtumas, kompleksiškumas, postmodernizmas, socialinis darbas, žmogaus teisès, kritinis mąstymas.
\end{abstract}

\begin{abstract}
The article addresses the problem of uncertainty in social work. The problem is analyzed in the context of domination of postmodern worldviews. Three types of uncertainty are distinguished: ontological, epistemological and procedural. Resting on various literature critical thinking, human rights discourse and client strengths perspective are presented as possible alternatives for decision making in a complex world.

KEY WORDS: uncertainty, complexity, postmodernism, social work, human rights, critical thinking.
\end{abstract}

DOI: http://dx.doi.org/10.15181/tbb.v69i1.1053

\section{Ivadas}

Jau tapo ịprasta šiandieninị pasauli apibūdinti kaip nuolat besikeičiantị, suartinantị ịvairias pasaulěžiūras, požiūrius ir kultūras, kartu reikalaujantị nuolat atnaujinti igūdžius ir gebejjimus orientuotis šioje prieštaringoje gausoje. Socialinio darbo profesija šiuo atveju nèra išimtis. Socialiniams darbuotojams kasdien tenka susidurti su įvairiomis dilemomis ar situacijomis, kurios neturi aiškaus sprendimo. Neapibrėžtumas tapo nuolatiniu jų profesinès veiklos palydovu. Ne veltui vienas iš bendrujų socialinio darbo studijų Lietuvoje tikslų - rengti specialistus, kurie gebėtų taikyti naujausias žinias, suderinti ịvairių bendruomenės grupių interesus, naudotis socialinès politikos galimybėmis, veikti neapibrėžtose situacijose. Natūraliai kyla poreikis išsamiau paanalizuoti neapibrėžtumo aspektus šiandienos socialinio darbo srityje, apžvelgti mokslinèje literatūroje siūlomas sprendimų gaires. Tai savo ruožtu suponuoja šio straipsnio tikslą: atlikti teorinę neapibrèžtumo aspektų socialiniame darbe analizę. 
Nūdienos socialinio pasaulio kompleksiškumas determinuoja problemų ir aplinkybių, su kuriomis kasdien tenka susidurti socialiniams darbuotojams, kompleksiškumą. Plečiasi socialinių problemų spektras ir jų mastas, auga ịvairesnių socialinio darbuotojo vaidmenų poreikis, kartu ir tarpinstitucinių susitarimų bei ịvairių sričių specialistų įtraukimo būtinybė. Kitaip tariant, plečiasi socialinio darbo ribos. Pagalba žmogui, modernios pasaulèžiūros eroje buvusi tiesiog ,veiksmu“, apibrèžta universalaus suvokimo, kas yra gerai, o kas - blogai, postmoderniame pasaulyje tampa labai priklausoma nuo konteksto ar susiklosčiusių aplinkybių. Šiandienos socialiniam darbuotojui būtina kompleksiškai mąstyti. Šiuo atveju svarbus nuolatinis savo patirties ir žinių perkratymas, jų kritiškas ịvertinimas, tai padeda turimas žinias ir patirtị pritaikyti besikeičiančioje realybejje. Socialinis darbas tampa kažkuo daugiau nei vien ,veiksmu“. Jis tampa refleksyvia, kritiniu mąstymu pagrịsta veikla, aprẻpiančia praktinius ịgūdžius, žinias, vertybes, mintis, jausmus ir veiksmus. Socialinis darbas - tai tarsi kūrybiškas pasirinkimo iš daugelio variantų veiksmas. Kaip ne kartą tvirtino R. Adams'as su kolegomis (2002; 2009), socialinis darbas - tai ne tik rinkimasis tarp dviejų (dažniausiai nepatenkinamų) sprendimų, bet ir inkliuzinis mąstymas, alternatyvių sprendimų paieška. Toks apibréžimas atmeta dichotomijomis grịstą požiūrị, kad jei padarysime tai, negalèsime atlikto ano, jei nuspręsime šitaip, negalèsime nuspręsti kitaip ir pan. Kiekviena socialinė grupe savo patirties reiškiniams prasmę suteikia per bendrą diskursą, todèl ji niekada nebūna vienpusè. Tik tai suvokęs socialinis darbuotojas gali priimti geriausius sprendimus. Tačiau būtent šis socialinio darbo ribų išsiplètimas, jo tapimas priklausomu nuo konteksto bei jame vyraujančio diskurso ir sukuria neapibrèžtumo, galimų sprendimų ịvairovès, neužtikrintumo pojūtį.

Neapibrèžtumas šiame straipsnyje apibūdinamas ir analizuojamas remiantis žinomu socialinio darbo teoretiku Robertu Adamsu. Drauge su kolegomis L. Dominelli ir M. Payne'u parengtoje knygoje „Practicing social work in a complex world“ („Socialinio darbo praktika kompleksiškame pasaulyje“) R. Adams'as (2009, p. 16) neapibrèžtumą socialiniame darbe skirsto ị tris tipus:

- ontologinis neapibrèžtumas: abejonès dèl savo vertybių, ịsitikinimų, emocijų, savęs ir supančio pasaulio suvokimo;

- epistemologinis neapibrèžtumas: abejonès dèl turimų žinių tinkamumo, patikimumo, pritaikymo ir kritinis jų vertinimas;

- procedūrinis neapibrèžtumas: abejonès dèl darbo organizavimo, paslaugų teikimo ir organizacijos veiklos.

Straipsnyje apžvelgsime visus tris neapibrèžtumo tipus. Straipsnio apimtis neleidžia atlikti išsamios visų trijų tipų analizès, todèl bus apsiribojama kiekvieno iš išskirtų tipų kai kurių aspektų atskleidimu, tikètina, padėsiančiu geriau suvokti ir pažinti neapibrěžtumo situacijas bei priimti geriausius sprendimus. 


\section{Ontologinis neapibrèžtumas}

Ontologija (gr. ontos - būtis) - tai požiūris ị pasaulio prigimtị ir jo funkcionavimo pobūdị, ị pasaulio reiškinių egzistavimo sąlygas ir jų tarpusavio sąsajas. Gyvename pasaulyje, kuriame moderni pasaulèžiūra užleidžia vietą postmoderniai. Pastaroji pati savaime yra neapibrèžtumo ir netikrumo lopšys, nes pasaulyje, kur ji dominuoja, nebelieka universalaus suvokimo, kas yra gerai, o kas blogai, mokslas praranda pasaulio reiškinių aiškinimo, o religija - moralinio autoriteto monopolius, įsigali gausybe skirtingų požiūrių, kurie visi traktuojami kaip lygiaverčiai.

Šią situaciją socialinio darbo kontekste gražiai apibūdina J. Pardeck'as, J. Murphy'is ir J. Choi'us (1994), jų teigimu, modernioje visuomeneje realybè buvo sudaryta iš taisyklių, įstatymų, lūkesčių ir pan., kurių nevalia savaip interpretuoti. Sveikata, normalumas, socialine deviacija apibrež̌ti griežtais empiriniais teiginiais. Tam naudoti demografiniai, fiziologiniai ir kiti rodikliai. Socialinè tvarka buvo palaikoma ribojant bet kokią interpretaciją. Postmodernioje visuomeneje socialinè realybė tampa apibrèžimų ir interpretacijų objektu, todèl socialinis darbuotojas ir klientas, užuot vadovavęsi standartiniais savo vaidmenimis ir bendravę jų apibrèžtose ribose, turètų patys kurti savo bendravimo (bendradarbiavimo) diskursą.

Šiuo metu plačiai taikomas sisteminis požiūris ị socialinį darbą taip pat pabrèžia linijinio mąstymo, matančio vieną priežastị ir vieną pasekmę, ydingumą, teigiama, kad kompleksiška socialinè realybe savaime koduoja multipriežastingumą ir multifinališkumą. Socialiniams darbuotojams svarbu kuo geriau pažinti kliento socialinį kontekstą ir jame vyraujančius diskursus, kad galètų identifikuoti galimų priežasčiu ir pasekmių sąsajas bei kurti efektyvų savo ir kliento diskursą. Deja, praktikoje dažnai pasitaiko gana mechaniškų, vienpusiškų situacijos vertinimų ir šabloniškų sprendimų. Tai suprantama, nes žmogus daug patogiau jaučiasi aplinkoje, kurią gali kategorizuoti, sudèlioti ị lentynèles ir aiškiai ịvardyti, kas yra juoda, o kas balta. Žmogiški ịpročiai kinta gerokai lečiau negu išorinis pasaulis, todèl ne vienas mūsų geriau jaučiamès aiškiame, dvipoliame moderniame pasaulyje negu chaotiškame ir kompleksiškame postmoderniame. Deja, situacijos supaprastinimas ar susiaurinimas, pritaikant dokumentuose reglamentuotas veiklas ar įstatymų nuostatas, taip siekiant išvengti neapibrèžtumo, nėra geriausia išeitis. L. Donskis šiuo požiūriu yra labai kategoriškas: „Negalime mąstyti tokiomis priešpriešomis kaip tiesa ir klaida arba absoliutus gèris ir visa apimantis, visur esantis blogis (...), turime įveikti savyje net mažiausią pagundą mąstyti priešybẻmis, nes tai labai panašu ị totalitarinių minties ir veiksmo projektų polinkị dažyti pasaulị tik juodai ir baltai“" (Donskis, 2009 p. 129).

Taigi postmodernioje visuomeneje tampa naudinga vadovautis netikrumo, neapibrěžtumo požiūriu, užuot likus prie modernios pasaulèžiūros, pagrịstos objek- 
tyvia realybe, besiremiančia išmatuojamomis, žinomomis ir numatomomis tiesomis. Kaip ir I. Niutono fizika, kurta numatomame ir išmatuojamame pasaulyje, buvo užginčyta A. Einšteino reliatyvumo teorijos, kalbančios apie erdvės ir laiko iliuziją. Socialiniai darbuotojai neturètų manyti, kad jie iš anksto žinos, kokie bus intervencijos rezultatai. Jie tik pastūmèja, o to postūmio poveikị lemia patys klientai. Socialiniams darbuotojams būtina atsižvelgti ị bendravimo su klientu kontekstą ir suvokti, kad jų žinios apie ṣ̨̌ kontekstą gali labai skirtis nuo kliento žinių. Juo labiau, kad mūsų pačių suvokimas, kaip mes pažịstame pasauli ir kaip pažịstame save, tampa vis labiau neaiškus (Pardeck, Murphy, Choi, 1994; Pozatek, 1994).

Vis dèlto socialinis darbas - glaudžiai su bendražmogiškosiomis vertybèmis susieta profesija, šis ryšys atskleidžia vieną svarbesnių postmodernios pasaulěžiūros dilemų. Požiūrių, diskursų, problemų, pasirenkamų pagalbos metodų įvairové, nors ir trikdanti, bet įmanoma aprépti ir priimti, tuo tarpu vertybinis reliatyvumas toli gražu ne kiekvienam priimtinas. Sunku įsivaizduoti profesionalų socialinị darbuotoją, skirtingose situacijose besivadovaujantị skirtingomis, ne visada tarpusavyje derančiomis vertybėmis. Vargu ar būtų teisinga, remiantis L. Donskiu, priimti moralinius, vertybinius sprendimus visiškai atsiribojus nuo dichotominio mąstymo, ištrynus ribas tarp to, kas gera, ir to, kas bloga tiek socialiniame darbe, tiek kasdieniame gyvenime. Aiški, nekintanti vertybinė pozicija yra kiekvienos asmenybės brandumo pagrindas.

Deja, vertybinis reliatyvizmas ,prasigraužè“ ị daugelị mūsų gyvenimo sričių ir išmuše pagrindą iš po kojų, teikusi pasitikejimo ir aiškumo. Dešimtyje Dievo ịsakymų užkoduotiems universaliems vertybiniams principams drauge su Bažnyčia prarandant moralinio autoriteto monopoliją, ieškoma kito pagrindo, ị kurị būtų galima atsiremti priimant vertybėmis grịstus sprendimus. Z. Brzezinskis knygoje „Nebevaldomas pasaulis“ (1998) kaip vieną iš nūdienos pasaulyje taikomų alternatyvų pateikia vyraujantị poslinkị nuo moralumo link legalumo, ịtvirtinantị teisètumą, kaip sprendimų prièmimo pagrindą. Tačiau, pasak autoriaus, tai nėra geriausia išeitis, nes legalumas gerokai susiaurina moralumo ribas ir negali būti laikomas tinkamiausiu vertybinio reliatyvumo sprendimu. Juk toli gražu ne viskas, kas yra teisèta, yra gerai, ir ne viskas, kas neteisèta, yra blogai. Socialiniams darbuotojams kartais tenka pažeisti vienokị ar kitokị reglamentą, kad patenkintų kliento gyvybinius poreikius ar užtikrintų saugumą.

Kitas šios dilemos sprendimo būdas - etikos kodeksai. Jie laikomi vertybiniu konkrečios srities specialistų veiklos pagrindu, kuris yra būtinas. Socialinio darbo profesija šiuo atveju ne išimtis. 1998 m. patvirtintame Lietuvos socialinių darbuotojų etikos kodekse siekiama ịtvirtinti konkrečias vertybes, kurių turètų laikytis kiekvienas šios srities profesionalas. Tačiau, kaip ir bet koks kitas konkrečią sritị reglamentuojantis dokumentas, etikos kodeksas yra bandymas šiandienini sudè- 
tingą ir ịvairialypi pasaulị ịvilkti ị vieną viskam tinkantị rūbą. Šiuo teiginiu jokiu būdu nesiekiama sumenkinti ar atmesti etikos kodekso, tiesiog norima atkreipti socialinių darbuotojų dèmesị ị postmodernios visuomenès realybę ir paskatinti juos kritiškai ịvertinti bet kokị jų veiklą reglamentuojantį dokumentą. Kaip teigia J. Ife'as (2012, p. 168), etikos kodeksuose dominuoja moderni pasaulěžiūra. Tuo tarpu socialinis darbas pamažu perima postmodernaus pasaulio principus ir vis labiau yra pasirengęs veikti neapibrèžtose, kontekstinèse situacijose. Todèl klaidinga manyti, kad etikos kodeksas gali pateikti atsakymus ị kiekvieną praktikoje kylantị klausimą. Nes praktika postmoderniame pasaulyje yra kur kas sudètingesnė ir prieštaringesnè negu modernumu grịstas etikos kodeksas.

Konceptas, galintis padèti socialiniams darbuotojams surasti atsakymus, kai etikos kodekso nebepakanka, yra žmogaus teisès. Nors socialinis darbas, kaip profesija, neatskiriamas nuo siekio užtikrinti socialinį teisingumą ir žmogaus teises, kasdieneje praktikoje žmogaus teisiu sąvoka, ypač ịvertinant jos galią šiandienos kontekste, vartojama per retai. Taip, žmogaus teisių diskursas nèra panacèja, jis susilaukia nemažai kritikos ir turi akivaizdžių trūkumų, tačiau nepaisant jų etika ir žmogaus teisès gali tapti puikiais partneriais. Galima sakyti, kad etikos kodeksas deklaruoja tam tikras žmogaus teises: kliento, socialinio darbuotojo ir pan. Etiškas elgesys šiuo atveju tampa tarsi šių teisių svarbos patvirtinimu ir ịgyvendinimo mechanizmu. Etika ir žmogaus teisès yra tarsi dvi tos pačios monetos pusės. Vis dèlto, pasak J. Ife'o (2012, p. 165-166), tam tikrų skirtumų galima ịžvelgti: etikos kodeksas turi aiškiau išreikštą kontrolès funkciją, ko negalima pasakyti apie žmogaus teisių diskursą, labiau besiremiantị moraliniais ịsipareigojimais. Etika yra labiau individualistinis diskursas, pabrěžiantis individualius sprendimus specifinèse situacijose, kuriose socialinis darbuotojas suvokiamas kaip individualiai priimantis individualius sprendimus. Žmogaus teisès labiau orientuotos ị grupinius klausimus, visai žmonių grupei aktualias teises. Kitaip tariant, etiškas sprendimas pirmiausia siejamas su socialiniu darbuotoju, tuo tarpu žmogaus teisès - su klientu. Etika yra introspektyvus, reflektyvus procesas, o žmogaus teisès orientuotas ị išorę.

Pastangos suvokti šiandienos realybę, pažinti savo ir kliento kontekstą reiškia darnos paieškas. Susitelkimas ties etika gali lemti vienpusiško požiūrio ị problemų sprendimą formavimąsi, kliento palikimą pasyvaus stebètojo, o ne aktyvaus dalyvio vaidmenyje. Atsigręžimas ị žmogaus teises gali tapti tinkama atsvara šiems procesams. Svarbu suprasti, kad ir postmoderniame pasaulyje mes kasdien darome šimtus moralès ir etikos principais paremtų sprendimų, tačiau mums vis dažniau pritrūksta išorinių, formalių nurodymų, kaip tai daryti. Tada vadovaujamės ne dokumentais ar kodeksais, o mūsų žmogiškaja morale. Kita vertus, socialinių darbuotojų priimami sprendimai reikalauja ne tik asmeninės, bet ir diskursu grịstos, interaktyvios moralès, kuri būtų priimtina ir suprantama klientui, jų grupei ar 
bendruomenei. Žmogaus teisių diskursas, kaip teigia J. Ife'as (2012, p. 172), šiuo atveju gali tapti vienu iš sprendimų, nes jis akcentuoja tuos dalykus, kurie apibrèžia žmogaus, žmogiškumo esmę, todèl gali būti suprantami ir priimtini didesnei daliai žmonių.

\section{Epistemologinis neapibrèžtumas}

Epistemologija (gr. episteme - pažinimas) - tai pažinimo teorija, aiškinanti, kaip mes žinome tai, ką žinome. Žinios, kuriomis remdamiesi suvokiame ir pažịstame pasaulị, mus pasiekia iš gausybès ịvairių šaltinių, o mokslas postmodernumo eroje praranda pasaulyje vykstančių reiškinių aiškinimo monopolį. Prieštaringos, keliančios sumaištį, pretenduojančios ị teisybę žinios, plūstančios iš gausybès šaltinių, yra viena svarbiausių neapibrèžtumo priežasčių. Straipsnio pradžioje socialinį darbą pristatėme kaip refleksyvią veiklą, aprèpiančią praktinius ịgūdžius, žinias, vertybes ir mintis. Jokia refleksyvi veikla nèra įmanoma be kritinio mąstymo. Kritinis mąstymas, nuolatinis gaunamų žinių analizavimas ir vertinimas yra vienas iš būdų ịveikti neapibrěžtumą. Ir priešingai, be kritinio mąstymo ir refleksijos, vien tik aklai priimant informacijos srautą, neapibrèžtumo ir prieštaringumo pojūtis tik didèja.

Kaip asmens savybė kritinis mąstymas yra igimtas arba išsiugdytas gebejjimas skeptiškiau, kritiškiau vertinti savo patyrimą, gebejjimas šią savybę tikslingai ir konstruktyviai panaudoti. Tai savų vertybių ir nuostatų suvokimas įvairovę pripažistančioje ir ją deklaruojančioje sąmonèje. Kompleksiška ịvairovė, pasak R. Adams'o ir kt. (2009, p. 5), šalia gausybės kitų formų pasireiškia:

- Šeimos pokyčiais, partnerystès, ištuokos atvejų gausèjimu, tai lemia formų ịvairovę, kartu reiškia ne tik klientų, bet ir institucijų su skirtinga teisine ar administracine atsakomybe ịvairovę bei būtinybę bendradarbiauti.

- Klientų problemų kompleksiškumu (pvz.: psichikos negalia, mokymosi sunkumai, globa ir kvaišalų vartojimas).

- Problemų tarpusavio sąsajų sudètingumu ir prieštaringumu. Skirtingi specialistai skirtingai mato ir sprendžia to paties asmens problemas, skirtingų sričių teisinis reglamentavimas numato skirtingus sprendimo būdus ir pan.

Kaip metodas kritinis mąstymas remiasi konstruktyvistiniu, postmoderniu mokymusi ir desstymu. Socialinio darbo kontekste jis aktualizuoja aktyvios veiklos reikšmę tiesiant tiltus tarp skirtybių, nežalojant silpnųų, neignoruojant marginalų, o įtraukiant juos ị bendruomenę. Tai tiltai tarp pastovumo ir pokyčių, padedančių pakeisti požiūrị ir transformuoti veiklą (Adams, Dominelli, Payne, 2002, p. 307). 
Poreikis keistis ir formuoti naujas socialinio darbo žinias pabrèžiamas vis dažniau. Apibendrinant R. Blundo (2013) žodžius, bręsta būtinybė svarbiausią socialinio darbo akcentą nuo dèmens „darbas“ (arba „veiksmas“, kaip minèta straipsnio pradžioje) perkelti ị dẻmenị ,socialinis“. Jo teigimu, tai būtų sugrịžimas prie profesijos ištakų, nes XX a. pradžioje socialinis darbas prasidejjo kaip socialinė veikla ir socialinės reformos, tačiau netrukus (ne be JAV vyravusios socializmo ir jam artimų idèjų baimès įtakos) pasuko link darbo su individu (Blundo, 2013, p. 29-30). Tuo metu sustiprèjo, o vèliau ir ịsivyravo medicininis, diagnostinis socialinio darbo modelis, paremtas šių sričių žiniomis. Vẻliau tokị požiūrị dar labiau sustiprino psichoanalizès ir ego psichologijos paplitimas. Medicininis modelis reiškia ligos ir negalavimo priežasties suradimą bei vaistų (gydymo) išrašymą. Kitaip tariant, tai, ką šiandien paprastai daro socialiniai darbuotojai, - identifikuoja problemą ir bando ją spręsti. Socialinio darbo, kaip mokslo srities, stiprèjimas nepakeite šiu tendencijų, nes kalbèta apie mokslinius diagnozavimo, sunkumų priežasčių nustatymo ir intervencijos metodų paieškas. Taip išsirutuliojo ị problemą orientuotas, arba medicininis, socialinio darbo praktikos modelis. Visa tai suformavo profesinę socialinio darbo kalbą, tapusia taisyklių ir susitarimų rinkiniu, kuris formuoja ir apibrèžia profesinès pasaulèžiūros ribas bei lemia socialinį darbo žinių turinị. Bèda ta, kad taip formuojamas žinių turinys toli gražu nebeaprėpia visų šiandieninès realybės aspektų ir tampa socialinių darbuotojų nusiskundimų dèl teorijos ir praktikos atitolimo priežastimi.

M. Herz ir T. Johansson (2011) pritaria, kad viena galimų tokio atitolimo priežasčių - stereotipiniai socialinių darbuotojų požiūriai ir polinkis ị psichologinius, medicininio modelio metodus. Tolstama nuo sisteminio požiūrio, dèmesys nuo visuomenès perkeliamas asmenybei, nuo konteksto suvokimo - šio konteksto stokai. Psichologiniai metodai ir požiūris turètų užleisti vietą socialiniam konstruktyvizmui, ị procesą orientuotam, dinamiškam mąstymui. Tokiam mąstymui, kuris nesiliauja kèlęs klausimų net ir paprastose situacijose, kuris suvokia, kad neịmanoma turèti visos informacijos ar žinoti absoliučios tiesos, mąstymui, pajègiančiam susitvarkyti su abejonėmis ir emocine sumaištimi, gebančiam pasimokyti iš klaidų. Taigi vèl grịžtame prie kritinio mąstymo, nes tik jis gali padèti „,prisijaukinti“ netikrumą, formuoti kitokias, šiandienį kontekstą atitinkančias socialinio darbo žinias ir paskatinti poreikị keisti nusistovejjusias paradigmas.

Vieną iš tokių paradigmos pokyčių, kaip alternatyvą medicininiam socialinio darbo modeliui, siūlo D. Saleebey ir kiti jo idèjoms pritariantys autoriai. Tai kliento stiprybes akcentuojantis socialinio darbo modelis. Jis reiškia ne tik stiprybių aspekto išryškinimą ịprastoje socialinio darbo veikloje, bet pasaulěžiūros, mąstymo ir kalbos priemonių pokyčius. Dėmesys kliento stiprybėms nėra tik viena iš socialinio darbo vertybių, tai kitoks mąstymas apie socialinị darbą. Tai posū- 
kis nuo problemos matymo link gebejjimo išlikti, nepaisant kančios ir sunkumų, įvertinimo. Ne vienas tyrimas rodo, kad skirtumai tarp socialinių darbuotojų intervencijos metu taikomų metodų yra nereikšmingi, o svarbiausias dalykas, turintis įtakos geresniems rezultatams, yra socialinio darbuotojo ir kliento tarpusavio ryšio užmezgimas, vilties klientui įkvėpimas, galimybių pokyčiams sudarymas (Blundo, 2013, p. 39-40). Todèl nevisiškai teisinga manyti, kad socialinis darbas apsiriboja kliento „diagnozès“ nustatymu ir šiai diagnozei rekomenduojamų gydymo būdų (socialinio darbo metodų) parinkimu, nes tokiu atveju nuvertinamas kliento ir jo situacijos unikalumas bei išskirtinumas. Stiprybes akcentuojantis požiūris būtent ir siekia atskleisti kliento situacijos sudètingumą bei individualumą, pamatyti platesnị kontekstą.

Kliento stiprybių paieška ir atskleidimas - viena iš galimybių transformuoti socialinio darbo praktiką ir kurti šiuolaikinị kontekstą atitinkančias žinias. Kita grịsti praktiką moksliniais tyrimais. Juo labiau kad kritinis mąstymas ir požiūris yra bet kokio tyrimo sudedamoji dalis. Baigę studijas socialiniai darbuotojai susiranda darbą, ịsilieja ị institucijos kolektyvą ir, deja, labai dažnai savo praktiką ima grịsti toje institucijoje nusistovejusiais ịprastais darbo metodais, nebandydami jų kritiškai įvertinti ar palyginti su studijų metu įgytomis žiniomis. Tai nebūtų problema, jei kiekviena institucija nuolat vertintų savo veiklą ir taikytų naujausias žinias, tačiau taip yra toli gražu ne visada. Čia ir išryškejja mokslinių tyrimų svarba socialinio darbo praktikoje. Jei gebėsime atsispirti institucijos rutinai, pasiremti studiju metu ịgytomis tyrimais grịstomis žiniomis arba atlikti savo tyrimą, daug svariau galèsime prisidèti prie socialinès gerovès kèlimo. Nereikètų bijoti žodžio tyrimas, nes socialiniai darbuotojai su vienokios ar kitokios formos tyrimais susiduria kasdien. R. Adams'as su kolegomis tvirtina, kad tyrimas yra svarbus socialinio darbo komponentas, nes:

- mes tyrinejjame nuolat, domimès žmonių gyvenimais, rašome ataskaitas, ịvertinimus, išvadas teismams ir kitiems specialistams, vertiname savo darbą ir jo rezultatus;

- socialiniai darbuotojai praktikai nuolat susiduria su paslaugų gavejų socialine patirtimi, jų gyvenime ir aplinkoje vykstančiais pokyčiais, tad nuolat reikia mąstyti apie tai, kaip jie paveiks priimamus sprendimus;

- tyrinėjimas gali padėti pakeisti ịprastą mąstyseną, vyraujančią paradigmą ir pasiūlyti naują požiūrị (Adams, Dominelli, Payne, 2009, p. 4).

Dėmesys tyrimams, gebejjimas pamatyti naujus duomenis kasdienëje veikloje gali tapti reikšmingu postūmiu ịveikiant kompleksiškos realybès kuriamą sumaištị ir neapibrèžtumą. 


\section{Procedūrinis neapibrèžtumas}

R. Adamsas greta ontologinio ir epistemologinio neapibrèžtumo skiria ir trečią formą - procedūrinį neapibrežtumą. Tai abejonès dèl darbo organizavimo, paslaugų teikimo ir organizacijos veiklos. Natūralu, kad socialiniai darbuotojai, po studijų pradejję dirbti, ịsitraukia ị vienokị ar kitokị kolektyvą su jau nusistovéjusiomis taisyklemis, ritualais ir profesiniu klimatu. Sunkiausia užduotis - suderinti atsineštas tyrimais grịstas žinias su darbo kolektyve nusistovejjusia praktika, ypač su senstelejusiais, dabarties sąlygų nebeatitinkančiais darbo metodais arba prieštaringomis atskaitomybès formomis. Tada ir susiduriama su viena iš procedūrinio neapibrèžtumo apraiškų. Galimus atskaitomybės institucijai ir profesiniam idealui prieštaravimus grafiškai pavaizdavo S. Banks (1999). Nors senokai publikuotos, jos mintys nepraranda aktualumo ir šiandieniame kontekste. Autore skiria dvi prieštaravimų ašis: institucijos rūpestis etiška praktika prieš institucijos rūpestị savo reputacija (vertikalioji ašis) ir darbuotojo atskaitomybe profesiniam idealui ir etikai prieš darbuotojo atskaitomybę institucijos reglamentui ir vadovams (horizontalioji ašis). Šios dvi susikertančios ašys sukuria keturis galimus profesinès veiklos klimato variantus, pavaizduotus 1 paveiksle.

Rūpestis institucijos profesine etika

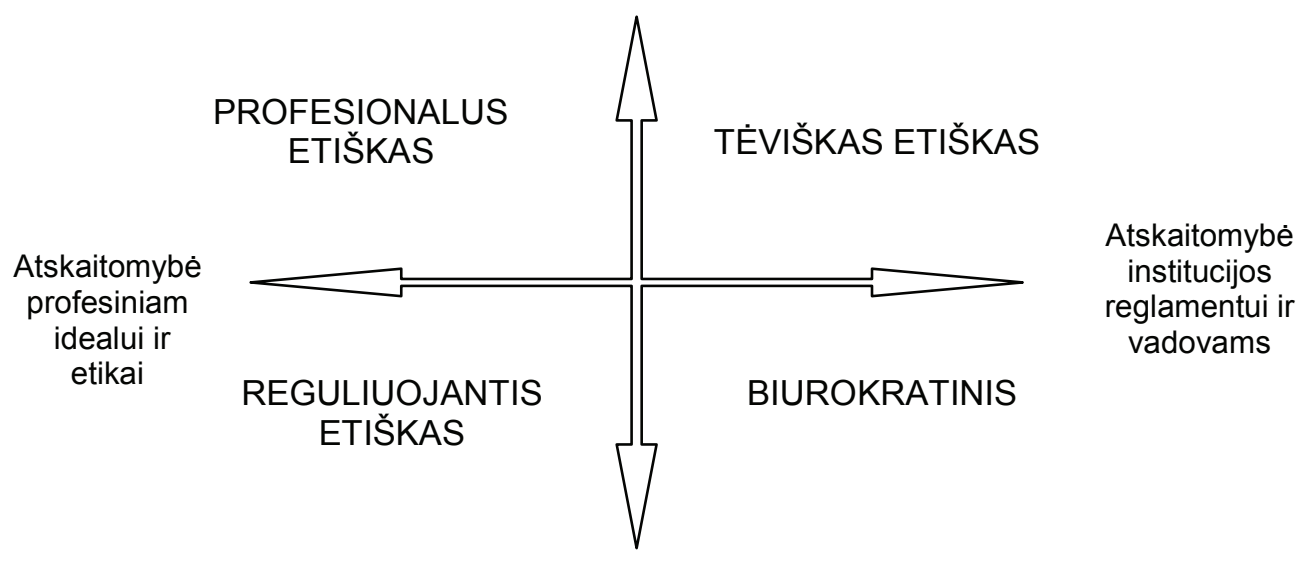

Rūpestis institucijos reputacija

1 pav. Institucijos profesinès veiklos klimatas (Banks, 1999, p. 47)

Pasak S. Banks, biurokratinis klimatas formuojasi, kai aiškiai nubrěžiamos komunikavimo ir atskaitomybès, profesinès veiklos ir sprendimo prièmimo galių ribos. Tada savarankiška veikla ir profesionalumas tampa problemiški, nes insti- 
tucijos poreikiai laikomi viršesniais. Deja, daugelyje Lietuvos institucijų, ypač didesnių valstybinių įstaigų, biurokratinis klimatas dominuoja, todèl socialinis darbuotojas, nors ir ịžvelgia pagalbos klientui galimybes, privalo paklusti reglamentui ir vykdyti jam priskirtas funkcijas.

Tèviškas etiškas klimatas sukuriamas institucijose, kurios siekia veikti teisingai, bet vengia suteikti darbuotojams savarankiškų sprendimų galimybę. Jos tampa „kontroliuojančiais tėvais“. Šiuo atveju profesionalumas taip pat nukenčia, nes tam tikras savarankiškumo laipsnis yra svarbi profesionalumo dimensija. Pvz.: aukšto lygio profesionalai privalo paklusti ịvairiems nurodymams ir procedūroms, vietoj to, kad savarankiškai priimtų sprendimus. Esant pirmiesiems dviem klimato tipams svarbus ir dar vienas aspektas: visada lengviau puoselèti profesines vertybes ir idealus, esant šalia mažiau galios turinčio asmens (socialinio darbo atveju - šalia kliento), tačiau tai gerokai sudètingiau atsidūrus šalia galingesnio (šiuo atveju šalia institucijos vadovo ar aukštesnio rango specialisto). Todẻl institucijose, kuriose dominuoja vadovybès kontrolè, socialiniai darbuotojai dažnai aukoja sprendimo laisvę dèl pastovumo ir užtikrintos ateities.

Kai klimatas reguliuojantis etiškas, darbuotojai jaučiasi atskaitingi idealui ar profesinei etikai. Darbuotojo autonomija čia yra siekiamybė, kurią vis dèlto reikia suderinti su organizacijos reputacija ar ịvaizdžiu visuomenèje. Tokios situacijos dažnos vykdant projektus, kai darbuotojo autonomija lyg ir nevaržoma, bet būtina įtikti finansuotojo reikalavimams, kad šis nenutrauktų paramos.

Galiausiai profesionalus etiškas klimatas vyrauja institucijose, kurios deklaruoja etiškos veiklos prioritetą ir suteikia darbuotojams autonomiją priimant sprendimus. Situacija iš pirmo žvilgsnio gali atrodyti ideali, tačiau realybejje poreikis pačiam priimti sprendimus, remiantis tik profesinès etikos normomis, darbuotojui gali tapti nepakeliama našta, nuolat sukeliančia izoliacijos, abejonių ar netikrumo būsenas.

Kaip matyti, nė vienas iš profesinès veiklos klimato tipų nepanaikina tam tikro netikrumo ar abejonių, tačiau savos situacijos suvokimas gali padèti lengviau surasti atsakymus ir priimti sprendimus, gal net išsiugdyti reikiamas charakterio savybes. Kaip teigia Z. Baumanas, ,žmogaus atsakomybei tobulai suplanuota erdvè bus nevaisinga, o gal ir visiškai nuodinga dirva. Visiškai aišku - atsakomybe nebręs, o ką jau kalbèti, kad tarps higieniškai grynoje erdveje, kurioje nesama jokių staigmenų, dviprasmybių bei konfliktų. İ savo atsakomybę gali rimčiau žiūrèti tik tie žmonės, kurie yra išmokę sunkaus meno veikti prieštaringumo ir netikrumo sąlygomis, nulemtomis skirtingumo ir ịvairovès“" (2007, p. 74-75).

Dar vienas procedūrinio neapibrež̌tumo aspektas, aktualus socialiniams darbuotojams, atsiskleidžia pažvelgus turbūt ị dažniausiai jų atliekamą veiklą - poreikių vertinimą. Socialiniai darbuotojai net galètų būti pavadinti profesionaliais po- 
reikių vertintojais. Sumaištị šiuo atveju kelia pozityvistinis, moderniai visuomenei būdingas požiūris ị poreikị kaip ị konkretų daiktą, kurị galima objektyviai ir tiksliai išmatuoti. Tačiau šiandieninèje kontekstualizuotoje visuomenëje net vadovaudamiesi turimais instrumentais ir formomis keli socialiniai darbuotojai vertindami to paties asmens poreikius greičiausiai gaus skirtingus rezultatus. Ar tai rodo, kad skiriasi jų kompetencija? Vargu, nes poreikių vertinimas, nors ir yra reglamentuota veikla bei šiame straipsnyje priskiriamas procedūrinio neapibrèžtumo sričiai, glaudžiai susijęs tiek su konkretaus kliento situacija, tiek su darbuotojo vertybėmis. Tikètina, kad smurtą patiriančio vaiko poreikius skirtingai įvertins konservatyvių, patriarchalinių ir liberalesnių, kosmopolitiškesnių pažiūrų socialiniai darbuotojai.

Tai, kad pripažįstame poreikių kontekstualumą ir vertiname juos kaip vertybių išraišką, o ne kaip objektyvų faktą, dar nereiškia, kad jų negalima profesionaliai ìvertinti. J. Ife'as (2012) šiandieninị socialinị darbuotoją, vertinantị kliento poreikius, mato kaip derybininką, išklausantị ir suderinantị kliento, jo šeimos, kaimynų, bendruomenès poreikius. Jo nuomone, ieškant tinkamiausio sprendimo padètų poreikių ir žmogaus teisių susiejimas. Poreikio patenkinimas, kaip siekiamas tikslas, gali būti ịvardijamas kaip žmogaus teisè. Jei sakome, kad bendruomenei reikia vaikų darželio, suprantame, kad be jo tèvai negalès ịgyvendinti savo teisès ị dalyvavimą darbo rinkoje; specialios ugdymo programos būtinos siekiant užtikrinti vaikų teisę ị mokslą ir t. t. Problema, pasak J. Ife'o (2012, p. 130), yra ta, kad su poreikiais susijusios teisès dažniausiai neišryškinamos ir lieka tik numanomos. Garsiai kalbama tik apie poreikius, o ne apie teises. Socialinis darbuotojas, neabejingas žmogaus teisių klausimui, turètų stengtis nuolat pabréžti žmogaus teisių komponentą, neatsiedamas jo nuo poreikių. Toks požiūris suteiktų aiškesnę perspektyvą ir sudarytų galimybes atrasti geriausius sprendimus.

Kartu nederètų pamiršti, kad žmogaus teisès yra universalios, tačiau poreikiai, per kuriuos šios teisès ịgyvendinamos, gali skirtis skirtingose kultūrose ar net mažesnèse socialinėse grupėse. Pavyzdžiui, teisè ị mokslą yra universali teisè, tačiau mokymosi poreikiai ịvairiose kultūrose gali skirtis. Šią teisę galima užtikrinti skirtingais būdais, pasitelkiant skirtingas struktūras ir procesus. Tai pačiai teisei ị mokslą užtikrinti galimi labai skirtingi poreikiai: vienur tai pastatai, kitur - kompiuteriai, dar kitur - vietinių gyventojų apmokymas, kitur - knygos.

\section{Išvados}

Kaip ne kartą minèta šiame straipsnyje, kompleksiškas, kontekstualizuotas pasaulis nuolat pateiks mums vis naujų, sudètingesnių, precedento neturinčių socialinių situacijų. Todèl tikètis, kad naujos žinios ar darbo metodai padès atsikra- 
tyti neapibrèžtumo jausmo, naivu. Juo labiau, kad pasaulis, kur dominuoja rinkos ekonomika ir viskas matuojama investicijų efektyvumu, neišvengiamai keis ir pati socialinio darbo pobūdį. Kaip tvirtina W. Kisthardt'as (2013, p. 54), socialiniams darbuotojams vis dažniau tenka galvoti ne apie reikiamas socialines paslaugas klientui, bet apie teikiamų paslaugų socialines pasekmes ar rezultatus. Rinkos dèsniai akcentuoja išleistų lèšų efektyvumą, todèl vargu ar bus tinkamai finansuojamos paslaugos, neduodančios konkrečių rezultatų. Todèl kuo toliau, tuo labiau teks kelti klausimą ne „kokias paslaugas reikètų suteikti?“, bet „kokios veiklos ir kokio bendradarbiavimo pageidauja paslaugos gavejas, kuris leistų pasiekti norimas socialines pasekmes?" Taigi socialiniams darbuotojams svarbiausia suvokti, kad neapibrèžtumas niekur neišnyks, todèl reikètų stengtis jị ,prisijaukinti“, užuot stengiantis jo atsikratyti. Šiame straipsnyje išskiriami žmogaus teisių diskursas, kliento stiprybes akcentuojantis socialinio darbo modelis patys savaime taip pat nepateikia atsakymų, tačiau jie gali padèti ị kliento socialinị kontekstą pažvelgti nauju rakursu bei priimti tinkamiausius sprendimus. Ypač dabartiniame socialinio darbo, kaip kūrybiško rinkimosi iš keleto alternatyvų, procese norètųsi pabrèžti kritinio mąstymo ir kritinès praktikos svarbą. Tik kritinis požiūris gali padèti išvengti vienos grubiausių klaidų - savo priimamų sprendimų motyvavimo tuo, kad taip yra priimta, taip buvo daroma anksčiau, visiškai neatsižvelgiant ị realios situacijos kontekstą. Tik kritiškai mąstydami socialiniai darbuotojai gali surasti taką tarp vertybinio reliatyvumo pinklių vienoje puseje, ir formalių, pasirinkimo ìvairovès nepripažįstančių sprendimų - kitoje.

Galų gale kritinis mąstymas svarbus ir suvokiant paprastą tiesą - postmodernizmas nèra akmenyje iškalta ir neginčijama tiesa. Juk žvelgiant iš postmodernizmo pozicijų, jis pats yra tik vienas iš galimų realybès aiškinimo būdų. Todèl visai nebūtina susitaikyti su juo ir priimti jị kaip neišvengiamybę. Svarbiausia naudotis tomis idejjomis ir požiūriais, kurie geriausiai padeda pažinti situaciją ir suvokti joje vykstančius procesus.

Gauta 20150105

Pasirašyta spaudai 20150317

\section{Literatūra}

Adams, R., Dominelli, L., Payne, M. (red.) (2002). Critical practice in social work. Basingstoke: Palgrave Macmillan.

Adams, R., Dominelli, L., Payne, M. (red.) (2009). Practising social work in a complex world. Basingstoke: Palgrave Macmillan.

Banks, S. (1999). Ethical issues in social work. London: Routledge.

Bauman, Z. (2007). Globalizacija. Vilnius: Apostrofa.

Blundo, R. (2013). Learning and practicing the strenghts perspective. Kn.: D. Saleebey (red.). The strenghts 
perspective social work practice. New Jersey: Pearson, p. 25-52.

Brzezinski, Z. (1998). Nebevaldomas pasaulis. Vilnius: Tvermè.

Donskis, L. (2009). Neapykantos formos. Vilnius: Versus aureus.

Ife, J. (2012). Human rights and social work. New York: Cambridge University Press.

Kisthardt, W. E. (2013). Integrating the core competencies in strengtts-based, person-centered practice. Kn.: D. Saleebey (red.). The strenghts perspective social work practice. New Jersey: Pearson, p. 23-78.

Pardeck, J. T., Murphy, J. W., Choi, J. M. (1994). Some implications of postmodernism for social work practice.

Social work, Vol. 39, No. 4, p. 343-346.

Pozatek, E. (1994). The problem of certainty: clinical social work in the postmodern era. Social work, Vol. 39, No. 4, p. 396-403.

\section{ASPECTS OF UNCERTAINTY IN SOCIAL WORK}

\section{Valdas Rimkus}

Summary

Social workers encounter various dilemmas and situations without clear solutions on everyday basis. Uncertainty has become a constant companion of professional social work activities. Naturally, it prompted a need to analyze the aspects of uncertainty in modern social work which turned into the aim of this article.

The ever increasing diversity and depth of social problems requires a wider range of social woker's roles and demands for interinstitutional cooperation. In other words, boundaries of social work expand. Social work becomes something more than just an "action". It morphs into a reflective, critical thinking-based activity which encompasses practical skills, knowledge, values, thoughts, emotions and actions. As R. Adams $(2002,2009)$ and his colleagues have repeatedly argued, social work is not just a plain choice between two (usually unsatisfactory) solutions, rather it's an inclusive thinking-based search for alternative solutions.

This article uses the definition of uncertainty provided by R. Adams (2009, p. 16) who distinguishes three types of uncertainty: 1) ontological uncertainty (doubts about one's values, beliefs, worldviews, emotions, perceptions of self and the environment); 2) epistemological uncertainty (doubts about the nature of one's knowledge, it's validity, extent and critical evaluation); 3) procedural uncertainty (doubts about organization of work, service provision and organizational practice).

In a postmodern society social reality becomes an object of definitions and interpretations thus requiring social workers to move from standart roles and practices towards creation of contextual discourses of communication and cooperation. The diverseness of attitudes, discourses, problems and support methods, albeit fairly disturbing, yet is possible to grasp and accept, whereas relativity of values might appear unacceptable to many. Sadly, the relativity of values becomes incre- 
asingly more apparent in a postmodern world. Thus various alternatives to ground moral desicion upon are being sought for. Shift from morality towards legality as described by Z. Brzezinski (1998) is one of them, another - establishment of various professional codes of ethics. However, according to J. Ife (2012, p. 168), codes of ethics are dominated by modern worldviews, thus are not capable to provide all the necessary answers in a postmodern reality. He argues that a concept of human rights might come in as a helpful supplement. Everyday social workers take hundreds of morals-based decisions yet the shortage of external, formal guidelines is what causes the uncertainty. Human rights discourse is based on ideas inherent in our human nature and therefore might serve as a ground for decision making which is understandable and aceptable to a bigger part of people.

Contradictory and confusing knowledge swarming from multiple sources is one of the causes of epistemological uncertainty. Only critical thinking, constant re-evaluation and analysis of received knowledge may help to reduce this uncertainty. In this context the need to change and reform the social work knowledge is emphasized, possibly by shifting the main emphasis from the "work" part towards the "social" part. The "work" part dominated social work practice throughout the last century focusing on personal issues, stimulating the psychologization of social work, loosing the context in favour of a person. D. Saleebey is among the ones who advocate the paradigm shift in constructing social work knowledge and practice. As one of the possible directions he sees the client strenghts perspective. This perspective means not only distinguishing client strenghts in everyday social work practice, but it also implicates changes in worldviews, thinking patterns, language and knowledge gathering. It's a shift from problem-based thinking towards thinking about survival and recovery. The search for client strengts is one of the possible ways to transform and create context related social work knowledge. Another way is to ground one's practice on research. Research in postmodern society is an inherent part of every social work practice, moreover, it is unseparable from critical thinking.

Engaging in independent social work practice after graduation is the time when social workers start to encounter procedural uncertainties. The article presents four organizational climates as put by S. Banks (1999) which may lead to different types of procedural uncertainty. Links between human needs and human rights are analysed as another possibility to reduce procedural confusion. However, some level of dilemmas and uncertainties is inevitable and even desirable, as according to Z. Bauman (2007, p. 74-75), responsibility will not ripen in clean and pure environment, devoid of any surprises, ambiguities and conflicts. Responsibility develops in conditions of uncertainty and contradictions. 
It's important for social workers to understand that uncertainties will not disappear, thus it is better to "tame" them instead of trying to get rid of them. The same goes with postmodernism. Postmodern perspective is one among many which try to explain the existing reality. Thus it's not necessary to accept it as an inevitability. The most important is to use the ideas and approaches which suit the given situation best and provide the understanding of ongoing processes. 
